\title{
Zinc Finger Protein GLI3
}

National Cancer Institute

\section{Source}

National Cancer Institute. Zinc Finger Protein GLI3. NCI Thesaurus. Code C17410.

Zinc finger protein GLI3 (1580 aa, 170 kDa) is encoded by the human GLI3 gene. This protein is involved in transcriptional regulation, limb development and signal transduction. 